\title{
The Inclusion of Knowledge Economy Concepts in the Omani Social Studies Textbooks
}

Jalila Al-Balushi ${ }^{1}$, Saif Al-Maamari ${ }^{2}$

\begin{tabular}{l} 
ARTICLE INFO \\
\hline Article History: \\
Received 19.12.2019 \\
Received in revised form \\
03.06.2020 \\
Accepted \\
Available online 01.10 .2020
\end{tabular}

\begin{abstract}
The study aims at identifying the degree of inclusion of knowledge economy concepts in social studies curriculum for grades (3-12) in the Sultanate of Oman for the concepts of knowledge economy. The data were collected and the concepts were constructed by the Delphi method over three consecutive rounds, The study was applied to the sample consists of 20 social studies textbooks for grades (3-12) at the rate of (20) books for the first and second semesters at the level of the three grades, The results showed that the first indicator: the institutional system of the state represents the highest degree of inclusion of the concepts of the knowledge economy. The ICT system index represents the lowest degree of inclusion of the concepts of the knowledge economy in the content of textbooks for grades 3-12. The results also indicated that post-primary education for grades 11 and 12 comes first in the degree to which they include the concepts of the knowledge economy according to the four indicators, followed by (5-10), while none of the textbooks of the first level of basic education on concepts of knowledge economy. The study recommended the need to include the concepts of the knowledge economy in different grades and stages, and to carry out more research and studies, renewable and continuous, which ensure the concepts of economy Knowledge in different textbooks and stages in line with the requirements of the knowledge economy. .
\end{abstract}

(C) IJERE. All rights reserved

Keywords:

Knowledge Economy, social studies textbooks, Omani education.

The knowledge economy began at the end of the twentieth century as a new type of economy resulting from the rapid and continuous development of knowledge, science and information and communication technology (ICT), which replaced labour, machinery and petroleum as sources of power and wealth in societies at the international and regional levels. The first emergence of the concept of knowledge economy dates back to the beginning of the twentieth century as a result of the increasing economic role of knowledge and the tremendous development of information and communication technology (Mohammed, 2014), which since its inception has been associated with many terms such as the new economy, digital economy, network economy and knowledge-based economy. All these terms converge on how knowledge is produced and distributed (Hansen, 2011), in the form of knowledge-based products and services that contribute to scientific and technological progress (Powell, 2004).

In advanced economies, the concept of knowledge economy is used to describe trends in which knowledge creation, generation and use in production as an increasingly important factor (Hogan \& Seidman, 2011). The knowledge economy is defined as "an economy that is based on the dissemination, production and adequate use of knowledge in all spheres of socio-economic activity, civil society, and political and private life in order to progressively upgrade the humanitarian situation, i.e., to establish human development through the building and successful distribution of human capacity" (UNDP; Mohammed bin Rashid Al Maktoum Foundation, 2015, 87). Powell and Snellman $(2004,201)$ define it as "the production and use of knowledge-intensive activities that rely more on intellectual capabilities than on physical inputs or natural resources and it includes key components of the knowledge economy and contributes to increased technical and scientific progress." Pedagogically, Dinmmock and Goh $(2011,219)$ define it as "enabling individuals to acquire, share, produce and use knowledge to improve the quality of human life". Al-Bustanji $(2011,97)$

\footnotetext{
e-mail: jalilh-m@moe.om Doctoral student, Sultan Qaboos University, orcid.org/0000-0002-6404-9378

e-mail: saifn@squ.edu.om Associate professor, Sultan Qaboos University, Colle ge of Education, orcid.org/0000-0002-0087-0896
} 
defines it as "an economy that depends on building an individual's deep academic knowledge and a great deal of orientation towards a particular profession while gaining knowledge".

The knowledge economy is characterized by the fact that information and knowledge are included in its components, processes and products as the most important modern economic resources that countries, organizations and institutions in all its forms try to benefit from to sustain their economic growth, in addition to other features and characteristics, including: First, globalization has transformed the world economy into a single market in which spatial and temporal barriers are eliminated (Al-Zu'bi, 2011) and became an open economy where the location effect was reduced due to the use of modern technological tools and techniques that led to the emergence of electronic commerce, markets and virtual organizations and facilitated their speed and accessibility (Tocan, 2012). It is also a digital virtual economy based on virtual work through digitization, networking and the Internet (Hadad, 2017), in addition to resulting dominance of the service sector, technological and information growth and production integration (Shiryaev, et al, 2016), through the emergence of knowledge goods that can be digitized and transmitted across networks and computers such as magazines, books, photographs, music, or digital processes that are products or services that rely on service providers with specialized knowledge such as information and search service that have reorganized the service function into a knowledge-based product (Ceri, 2001).This economy is also characterized by flexibility and adaptability to the rapid and continuous development and renewal and generation of new intellectual products (Batarseh, 2005), and its ability to create new intellectual, knowledge and non-knowledge products unknown previously in the markets by investing in scientific and technical production based on research and development, patents and knowledge flow (Arundel, 2005). It is also an economy in which it is difficult to enforce tax laws and customs and non-tariff restrictions (Abu Jahla, 2014) and is subject to the law of increasing revenues and decreasing costs while continuing to employ and expand the use of highly skilled workers that interact with continuing education and training (UNDP; Mohammad bin Rashid Al Maktoum, 2015).

The knowledge economy is based on four main pillars: (1) the institutional system of the state and the resulting economic incentives that allow the development and allocation of resources, the promotion of entrepreneurship, and the promotion of the creation, dissemination and application of knowledge efficiently and effectively (World Bank, 2007), (2) the research and development system: an effective innovation system consisting of companies, research centres, universities, consultants and organizations that enable them to cope with the knowledge revolution, and to benefit from the growing stock of global knowledge and its absorption and adaptation to local needs (Sundac \& Krmpotic, 2011), (3) the education and training system: an effective and productive education system that meets the requirements of the knowledge economy and ensures the flow of knowledge between individuals, companies and institutions for the transfer of knowledge to society (Hogan, 2011) and educated and skilled individuals capable of generating, sharing and using knowledge (World Bank, 2003), (4) the information and communication technology (ICT) system, which facilitates effective communication between institutions, and the dissemination and processing of knowledge and information (Robertson, 2008).

As these pillars increase the quantity and quality of the pool of knowledge available, leading to increased productivity and thus economic growth of countries (Tocan, 2012), most international indicators rely on these four requirements and pillars that measure countries' ability to generate, adopt and disseminate knowledge and their readiness to compete among them (Mikhmar; Abu Taha, 2009). This is what made the researchers to take advantage of these four requirements, which were addressed by some global indicators of the knowledge economy, to derive its concepts. These indicators included (1) the index of the Organisation for Economic Co-operation and Development (OECD, 1996), (2) the index of Statistics Australia (APEC, 2000), (3) European Union Index (ECKEI, 2008), (4) World Bank Index (KAM, 2005), (5) the Arab Knowledge Index (2016) to come up with a list of the final concepts of knowledge economy after judged by the Delphi method over three consecutive rounds to analyze the availability of the content of the textbooks of the social studies curriculum for grades (3-12) in the Sultanate of Oman.

This study stems from four main reasons First, curriculum planning and principles are based on the choice of knowledge that should prepare students not only for employment but also provide them with the knowledge, skills and abilities that will help them continue in those jobs (Yim, 2004). Therefore, the importance of the textbook as a tool for the implementation of the curriculum stands out - despite the 
scientific and technical progress in the broad methods and tools to implement the curriculum- and goes beyond its function as a storehouse of information and facts only (Abu Lebda, 2007), to be an honest translation of the curriculum and the first reference for the teacher as a source of organized information and reference for planning and implementation and motivation of students and the first reference for the student in the learning process (Khatib; and $\mathrm{Al} \mathrm{Zu'bi} \mathrm{2009).} \mathrm{Second,} \mathrm{the} \mathrm{main} \mathrm{role} \mathrm{of} \mathrm{the} \mathrm{social} \mathrm{studies} \mathrm{curriculum} \mathrm{is}$ to study the relationship between the human and the society in which he lives and the relationship of that society with other societies, and study the fields of activity and interactions of man and his relationship to his environment and the problems that resulted from those interactions (Adwan, 2009). It is also a source of social learning and social education by raising the interest of learners of the social problems present and their conscious participation in facing the problems of their society and knowledge of their reality for the world and work to improve and develop this reality (Abdulrahman, 2012). It also contributes to the development of individual's awareness of the imperative of social change in the light of global change and prepare it to accept such change and encourage them to be effective agents in making change for the benefit of themselves and the society in which they live (Ziyadat, Qatawi, 2010).Third, educational studies and research dealt with knowledge economy in various aspects such as (Abd Al Lat, 2009), which aimed to identify the degree to which high school students in Jordan possess the technological skills needed to learn the social studies curricula developed towards the knowledge economy, and the degree to which students possess the technological skills needed to learn the social studies curricula developed towards the knowledge economy from the perspective of students themselves, using a questionnaire consisting of (75) skills prepared in the light of identifying a list of technological skills necessary to learn the curricula of social studies. The findings indicated that students possess the technological skills necessary to learn social studies curricula with a medium degree, the highest of which is in the basic computer skills knowledge and the least in the use of technological learning tools and resources from the point of view of the students themselves. The results showed that the most highly skilled students had the skills to use the World Wide Web and LAN in schools, and the lowest was GIS-related skills. The study recommended the use of the list of skills developed, and the results of measuring the degree of possession in the development of social studies in the second phase of educational development towards the knowledge economy.

As for the evaluation of social studies textbooks in the light of the knowledge economy, the study of $\mathrm{Al}$ Edwan and Hamaidi (Al Edwan \& Hamaidi, 2010) aimed to evaluate the books of social and national studies from grades (1-3) in the light of the criteria of knowledge economy from the point of view of (174) teachers of Madaba Governorate in Jordan for Elementary stage in Jordan. It used descriptive methodology through the application of a questionnaire, which addressed five criteria for evaluation of the knowledge economy included: thinking skills, self-assessment skills, communication skills, technology skills and research skills. Each criterion has eight paragraphs explaining the required skills. The results highlighted that the content of the textbooks of social studies does not refer directly to the philosophy of the knowledge-based economy and that there is an attempt to incorporate the standards of knowledge economy in the social and national studies textbooks in the first three grades. However, this attempt of the Jordanian education system needs to integrate the standards of thinking skills more effectively in order to have more implications.

The study (Assaf, 2013) aimed to verify the extent of awareness of teachers of social studies of their teaching roles in the light of curricula based on knowledge economy. The sample of the study consisted of (125) teachers of social studies (history, geography, social field teacher) in the Amman II Directorate of Education selected by a simple random method, using a special tool applied to the study sample after verifying its validity and consistency. The results of the study revealed that teachers' awareness of their teaching roles in the light of curricula based on knowledge economy was high, and that there are statistically significant differences in teachers' awareness according to the variable of educational qualification in favor of teachers with master's degree, and there are no statistically significant differences in teachers' awareness according to experience, specialization, and gender variables.

Mohammed's study (2015) aimed to identify the effectiveness of a proposed training program based on knowledge economy to develop the performance skills of teachers of social studies and information generation skills of their students through a sample of (20) teachers from Cairo governorate and (100) students from their students using an observation card for teachers' performance and testing of information generation skills for students. The results indicated that there are statistically significant differences between 
the average scores of teachers and pupils in the pre- and post-application in both observation card and test of information generation skills in favor of telemetry. One of the study's recommendations was to reconsider teacher-training programs to focus on specialized skills and cognitive and social meta to raise their competencies in planning, implementing and evaluating the educational process.

At the level of studies dealing with the concepts of knowledge economy, the study (Taman, 2015) aimed to build a proposed model based on integrated learning to develop the curricula of economics in commercial secondary schools to develop the concepts of knowledge economy in the information age. A questionnaire of concepts of knowledge economy related to the activity of e-commerce was applied on a sample of (102) teachers. It consisted of (35) concepts in which the content of the curriculum of economics for grades 1, 2 and 3 secondary was analyzed and their existence to economics teachers in secondary schools was determined. The results showed that the content of the economics curriculum includes (6) of the concepts of the tool of study, and that economics teachers in secondary schools do not possess most of the concepts of the list. The study recommended the need to include these concepts in the content of the curriculum, and holding training courses that contribute to the acquisition of these concepts by teachers.

Fourth, referring to previous literature, studies and research - within the limits of the study - researchers noted the lack of studies that deal with the knowledge economy in social studies curricula and the lack of studies that adopt the concepts of knowledge economy through its indicators and the degree of inclusion in the curricula in general and social studies curricula in particular. The researcher also noted the absence of any studies on the social studies curriculum in the light of the knowledge economy at the local level in the Sultanate of Oman, although technology and knowledge society is one of the pillars of the philosophy of education in Oman, some of the objectives of which were the production and dissemination of knowledge and technology, and promotion of awareness of the importance of knowledge economy, and the acquisition of competencies and skills necessary for the knowledge society (General Secretariat of the Education Council, 2017).

Based on the above and emphasizing the importance of the curriculum and the need to transform it in line with the requirements of the knowledge economy and its importance in achieving the objectives of the knowledge economy, this study came to analyze the social studies textbooks for grades (3-12) at the level of the three educational stages in school education in the Sultanate of Oman to find out the extent to which they include the concepts of knowledge economy and the degree of their inclusion according to indicators of knowledge economy and different educational stages and come to conclusions by analyzing and recommending what the results of the study require in line with the concepts of knowledge economy and developments and requirements of knowledge economy.

\section{Situation of the Problem}

Education is of great importance to the service, economy and development of societies, as it contributes to raising the efficiency of the human element and the development of knowledge and skills, making spending on education a human investment that generates moral and material return on individuals and communities. Economic development in the light of the knowledge economy depends on investments in education and training (Salem, 2014), which are seen as a productive development process and a long-term investment (Boulbaa, 2013) and the most important sources of international competition and the key to entering the era of knowledge economy and the development of societies through the development of human capital, which is the focus of the educational process (Juma, 2009). The knowledge economy is receiving a great deal of attention from the educational side through many economic and cultural activities that clearly affect the educational systems, especially with regard to the philosophy of these systems, policies, curricula and performance strategies (Namrawi, 2014), which has a distinctive and continuous support, especially in the field of investing and empowering human resources as the knowledge capital capable of creating community development in all its dimensions in light of the limited financial and natural resources (Al-Barrak, 2011).

In the light of the interest of most of the previous studies and research - within the limits of the study to include the topics of knowledge economy for university education and the lack of studies and research that dealt with knowledge economy in school education, and proceeding from the National Strategy for Education 2040, which emanates from the vision of building human resources that possess the skills 
necessary for work and life to live productive in the world of knowledge and qualified to adapt to the changes of the times and achieve alignment between the outputs of the education system and the requirements of the work sectors in the country and improve the quality of the educational system and promote innovation, creativity and scientific research in the school education sector (Oman Education Symposium, 2014). This study seeks to answer the following questions:

\section{Aim of the Study}

The present study aims to achieve three aims, which is as follows:

1. Determine the degree to which the content of social studies textbooks for grades (3-12) in the Sultanate of Oman includes the concepts of knowledge economy according to the requirements of the four list of knowledge economy.

2. Discover the difference between the inclusions of the concepts of knowledge economy in the content of social studies textbooks for grades (3-12) according to the way they are included.

3. Define the difference between the inclusions of the concepts of knowledge economy in the content of social studies textbooks for grades (3-12) according to the different stage of education.

\section{Methodology}

\section{Method}

The present study is adopted a descriptive and analytical approach. The phenomenon to be studied, is described accurately and expressed qualitatively by describing its characteristics or quantitatively by clarifying the extent or magnitude of this phenomenon (Al-Takrouni, 2012) to analyze the content of the textbooks of social studies for grades (3-12) and come up with the conclusions and recommendations of the study. The researchers collected the data from the study sample, social studies textbooks for Grades (3-12) using the method of content analysis and then analyzing and interpreting this information and displaying the results.

\section{The Sample}

The study was applied to the content of social studies textbooks for grades (3-12) in the following grades: (34) which represents the first cycle of basic education, grades (5-9) which represent the second cycle of basic education, and grades (11-12) which represents the post-primary stage, which includes both mandatory and elective courses. The total number of books of this curriculum (20) books as shown in Table 1:

Table 1: Distribution of study population

\begin{tabular}{cccc}
\hline No & Educational level & Grade & No. of books \\
\hline $\mathbf{1}$ & First Cycle & $3-4$ & 4 \\
$\mathbf{2}$ & Second Cycle & $5-10$ & 10 \\
$\mathbf{3}$ & Post Basic & $11-12$ & 6 \\
& Total & & 20 \\
\hline
\end{tabular}

\section{Validity and reliability of the study tool}

To validate the study tool, the list of concepts of knowledge economy is constructed through the following international and global indicators: (1) OECD Index (OECD, 1996), (2) APEC Index by Economic Commission (APEC, 2000), (3) Australian Bureau of Statistics Index (Australian bureau of statistics, ABS, 2000), (4) World Bank Index included in Chen \& Dahlman (2005), (5) EU Knowledge Economy Indicators (European Commission Knowledge Economy Indicators, 2008), (6) Arab Knowledge Index (UNDP; Mohammed bin Rashid Al Maktoum Foundation, 2015), in addition to benefiting from the theoretical literature of studies dealing with knowledge economy. 
The list was judged using the Delphi method, which is one of the most prominent methods adopted in future studies, a set of procedures to predict the future by formulating a collective judgment on a particular subject for which no accurate information is available (Tarkhan, 2014), through a group of specialized experts to reach a consensus leading to agreement on the desired goal (Sharif, 2016), over three consecutive rounds. It was presented to (85) arbitrators from decision makers, experts and academics in the economic, technological and educational fields during the period from 13/1/2017 to 29/04/2017. The final list of concepts of knowledge economy consisted of (142) concepts, which were divided according to the four requirements and pillars of knowledge economy. Table 2 presents the classification of these concepts according to knowledge economy indicators:

Table 2: Classification of concepts of knowledge economy

\begin{tabular}{|c|c|c|c|c|}
\hline No & $\begin{array}{c}\text { Knowledge Economy } \\
\text { Indicators }\end{array}$ & Sub classification of concepts & $\begin{array}{c}\text { Total } \\
\text { Concepts }\end{array}$ & Total \\
\hline \multirow[t]{3}{*}{1} & \multirow{3}{*}{ 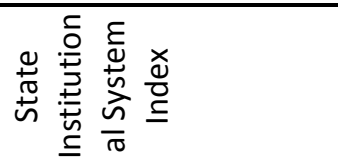 } & Organizational concepts & 11 & \multirow{3}{*}{42} \\
\hline & & Legal Concepts & 8 & \\
\hline & & Economic concepts & 23 & \\
\hline \multirow[t]{2}{*}{2} & \multirow{2}{*}{ 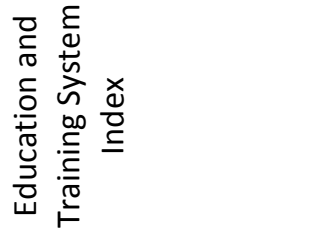 } & Concepts related to individuals & 7 & \multirow[b]{2}{*}{20} \\
\hline & & Program and education concepts & 13 & \\
\hline \multirow[t]{3}{*}{3} & \multirow{3}{*}{ 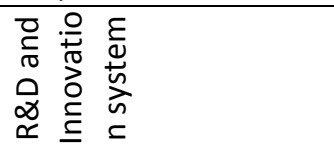 } & Concepts related to knowledge & 12 & \multirow{3}{*}{33} \\
\hline & & Research-related concepts & 10 & \\
\hline & & Concepts related to innovation & 11 & \\
\hline \multirow[t]{3}{*}{4} & \multirow{3}{*}{ 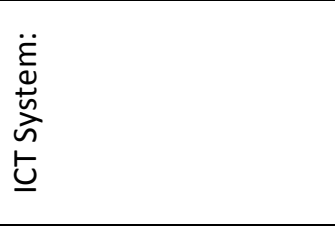 } & Technology sector concepts & 19 & \multirow{3}{*}{47} \\
\hline & & $\begin{array}{l}\text { Concepts related to electronic } \\
\text { commerce }\end{array}$ & 5 & \\
\hline & & $\begin{array}{l}\text { Concepts related to electronic } \\
\text { commerce } \\
\end{array}$ & 23 & \\
\hline 5 & & Total of Concepts & & 142 \\
\hline
\end{tabular}

\section{Statistical analysis}

1. Frequencies related to all concepts of knowledge economy according to the four requirements of knowledge economy.

2. Percentages of each of the four indicators and their ranking according to their importance in the light of the percentages achieved.

3. The stability of the analysis was verified through the use of an external analyst who is the supervisor of the social studies curriculum at the Ministry of Education to analyse the content of three books of the content of the social studies books for grades (3-12) for the first and second semesters after providing them with the rules and procedures of analysis agreed with the researcher. The coefficient of agreement between the two analysts was calculated using the holisti transaction and Table (3) shows the coefficients of the agreement between the first and second analysis and can be said to be reliable coefficients.

Table 3: Analysis Stability Coefficient Table

\begin{tabular}{lccc}
\hline \multicolumn{1}{c}{ Categories } & First analysis & Second analysis & Stability\% \\
\hline Concepts of Knowledge Economy in Social Studies & & & \\
$\begin{array}{l}\text { Textbooks for Grades } 3 \text { and } 7 \text { and Economic } \\
\text { Geography (11) }\end{array}$ & 81 & 77 & $95 \%$ \\
\hline
\end{tabular}




\section{Results and discussion}

Results of aim 1: Determine the degree to which the content of social studies textbooks for grades (3-12) in the Sultanate of Oman includes the concepts of knowledge economy according to the requirements of the four list of knowledge economy.

To achieve aim number 1 , the sum of frequencies and percentages for each of the four indicators was extracted. Table 4 shows the results.

Table 4: Frequencies of concepts of knowledge economy according to indicators of the list of knowledge economy

\begin{tabular}{|c|c|c|c|}
\hline No & Indicators & Total & Percentage \\
\hline 1 & Indicator 1: The institutional system of the State & 376 & $54.97 \%$ \\
\hline 2 & Indicator II: Education and training system & 81 & $11.84 \%$ \\
\hline 3 & $\begin{array}{l}\text { Indicator 3: Research, development and } \\
\text { innovation system }\end{array}$ & 148 & $21.64 \%$ \\
\hline 4 & $\begin{array}{l}\text { Indicator 4: Information and Communication } \\
\text { Technology (ICT) }\end{array}$ & 79 & $11.55 \%$ \\
\hline 5 & Total & 684 & $100 \%$ \\
\hline
\end{tabular}

The results in Table 4 indicate that the inclusion of the concepts of knowledge economy in the content of social studies textbooks for grades (3-12) reached (684) frequencies, most of which was in the first indicator related to the institutional system of the state by (54.97), while the three indicators were included in small percentages. This gives a general indication that the concepts of knowledge economy are not fully integrated into these books. Researchers attribute the poor inclusion of these concepts to the fact that the current curricula were prepared at a time that preceded the increasing discourse of the state in focusing on the importance of the transformation to the knowledge economy, which has increased in recent years. These curricula were supposed to keep pace with the transitions to integrate into the knowledge economy at the global level in general and at the local level in particular in the inclusion of their content and concepts in it. Educational institutions are supposed to predict future transformations and work to keep pace with their curriculum so that they can prepare individuals who can interact with the world with its various changes. This is confirmed by the Omani philosophy of education issued in 2017, one of the most important principles of which is the knowledge and technology society, which is achieved through enhancing awareness of the importance of the knowledge economy from the production, dissemination and employment of knowledge and technology, the localization of knowledge and technology and building self-capacity in the areas of research and technological development (General Secretariat of the Education Council, 2017).

The results also indicate that the first indicator, the institutional system of the state, represents the highest degree in the inclusion of concepts of knowledge economy with a total of 376 frequencies and not exceeding $(54.97 \%)$. Although it ranks first, this percentage is rather small. The concepts of the Research, Development and Innovation System Index included total of (148) frequencies with a rate not exceeding $(21.64 \%)$, which is less than half of the inclusion of the first indicator. The concepts of the index of the education and training system came in third place in terms of inclusion with total frequencies (81) with a percentage not exceeding $(11.84 \%)$, which is half of the percentage of the concepts of the previous indicator. Finally, the index of the Information Technology and Communications System (ICT) ranked last with a total frequency (79) and a percentage not exceeding (11.55).

This may be due to the fact that the curricula of social studies are integrated into one textbook that includes the three areas of social studies: history, geography and civic education. The content is thus divided into three areas that do not provide an opportunity to delve deeper into these specialized concepts at the level of the four indicators. The nature of the concepts of knowledge economy and the nature of dealing with topics more close to economic concepts, which despite the importance of the economy today, a future textbook deals with various aspects, especially in the stage of post-basic education, which is supposed to focus on profound aspects of specialization such as focusing on these concepts. The social studies curricula in terms of 
the nature of the treatment of topics focus on physical geography, which leads to a flaw in the concepts of knowledge economy. This may be due to the lack of a renewed educational document for social studies that embraces the incorporation of renewable concepts such as those of the knowledge economy. In the last twenty years since the start of basic education in Oman (1998-2018), the matrix of the sequence of social studies has not been reviewed. The decision was issued in November 2018 (Ministry of Education, 2018), i.e., the renewal requires a very long period, and it is known that during this period, the world is witnessing very large and rapid changes.

The MOE's interest in recent years has changed from simply seeking to increase student enrollment rates to seek to improve the quality and relevance of education to the labor market in order to prepare students to meet the challenges of the knowledge economy, based on the recommendations of the report "Education in Oman" prepared by the Ministry of Education in cooperation with the World Bank (2012). This report pointed out that the main challenge facing the education sector in the Sultanate is to develop the quality of educational outputs, that the quest for quality improvement is the main priority of the government in the field of education, and that assessment of the learning and performance of students - at the national and international levels - falls short of government expectations and below the levels achieved in many countries. However, the social studies curricula have not been developed and have not kept pace with the new changes and changes in the context of the state, public and private sector tendencies towards the knowledge economy, which is confirmed by previous findings.

Results of aim 2: Discover the difference between the inclusions of the concepts of knowledge economy in the content of social studies textbooks for grades (3-12) according to the way they are included.

To achieve aim 2, the sum of frequencies and percentages for each of the four indicators was extracted and the method included. Table 5 shows the results related to this question:

Table 5: Frequencies of the concepts of knowledge economy according to the indicators of the list of knowledge economy and the way they are included

\begin{tabular}{|c|c|c|c|c|c|c|c|}
\hline Indicators & 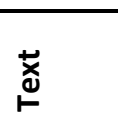 & 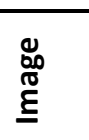 & $\sum^{\frac{2}{\pi}}$ & $\frac{0}{\frac{0}{0}}$ & $\begin{array}{l}\frac{5}{\pi} \\
\frac{\pi}{U}\end{array}$ & $\begin{array}{l}\frac{\varepsilon}{\pi} \\
\frac{5}{00} \\
\frac{\pi}{0}\end{array}$ & 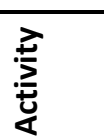 \\
\hline Indicator 1: The institutional system of the State & 311 & 0 & 0 & 5 & 0 & 11 & 49 \\
\hline Indicator 2: Education and training system & 71 & 0 & 0 & 3 & 0 & 1 & 6 \\
\hline $\begin{array}{l}\text { Indicator 3: Research, development and } \\
\text { innovation system }\end{array}$ & 122 & 0 & 1 & 0 & 0 & 5 & 20 \\
\hline $\begin{array}{l}\text { Indicator 4: Information and Communication } \\
\text { Technology (ICT) }\end{array}$ & 63 & 4 & 0 & 0 & 0 & 1 & 11 \\
\hline Percentage & $\begin{array}{c}567 \\
82.9 \%\end{array}$ & $\begin{array}{c}4 \\
0.6 \%\end{array}$ & $\begin{array}{c}1 \\
0.1 \%\end{array}$ & $\begin{array}{c}8 \\
1.2 \%\end{array}$ & $\begin{array}{c}0 \\
\% 0\end{array}$ & $\begin{array}{c}18 \\
2.6 \%\end{array}$ & $\begin{array}{c}86 \\
12.6 \%\end{array}$ \\
\hline
\end{tabular}

The results of Table 5 indicate that the concepts of knowledge economy emerged with a high percentage in the form of texts. Then came the activities ranked second with a total of (86) repetitions (12.6\%). Figures, tables and maps were low with a total frequencies of (18), (8) and (1), and percentages of $(2.6 \%),(1.2 \%)$ and $(0.1 \%)$, respectively.

This may be due to that the curriculum in the Sultanate is based on a philosophy based on knowledge where it is concerned with the text and pay more attention to it than images, maps and graphs, and therefore the texts that provide knowledge. It is logical that the activities come second because they are linked to the texts presented in the curriculum. The nature of the social studies curriculum is assumed to be more present in maps, images and graphs as the nature of this science is based on this type of method of inclusion. This may explain the weakness of educational outcomes in school education in the skills of interpretation of maps, images and graphs. This is recommended by Al-Baloushi (2014), who recommended the need to include the largest number of illustrations and reconsider the illustrations that suffered from some deficiencies in the standards of artistic design in the curricula of social studies in the Sultanate of Oman.

Results of aim 3: Define the difference between the inclusions of the concepts of knowledge economy in the content of social studies textbooks for grades (3-12) according to the different stage of education. 
To achieve this aim, the total number of frequencies and percentages for each indicator was extracted and then for the indicators combined for grades (3-12). Table 6 shows the results of the question.

Table 6: Frequency and Percentages of Knowledge Economy Concepts by School Level

\begin{tabular}{|c|c|c|c|c|c|c|c|c|c|c|c|c|}
\hline \multirow{4}{*}{ 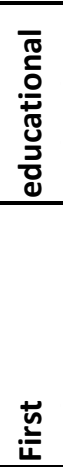 } & \multirow{2}{*}{\multicolumn{2}{|c|}{$\begin{array}{l}\text { Grade } \\
\text { Subjec } \\
t\end{array}$}} & \multicolumn{2}{|c|}{$\begin{array}{l}\text { Indicator 1: The } \\
\text { institutional } \\
\text { system of the } \\
\text { State }\end{array}$} & \multicolumn{2}{|c|}{$\begin{array}{l}\text { Indicator 2: } \\
\text { Education and } \\
\text { training system }\end{array}$} & \multicolumn{2}{|c|}{$\begin{array}{c}\text { Indicator 3: } \\
\text { Research, } \\
\text { development and } \\
\text { innovation system }\end{array}$} & \multicolumn{2}{|c|}{$\begin{array}{c}\text { Indicator 4: } \\
\text { Information and } \\
\text { Communication } \\
\text { Technology (ICT) }\end{array}$} & \multirow{2}{*}{$\begin{array}{l}\bar{\pi} \\
\stackrel{0}{0}\end{array}$} & \multirow{2}{*}{ 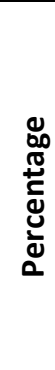 } \\
\hline & & & $\begin{array}{c}\text { Freque } \\
\text { ncy } \\
\text { Total }\end{array}$ & $\begin{array}{c}\% \\
\text { Percent } \\
\text { age }\end{array}$ & $\begin{array}{c}\text { Freque } \\
\text { ncy } \\
\text { Total }\end{array}$ & $\begin{array}{l}\text { Percent } \\
\text { age }\end{array}$ & $\begin{array}{c}\text { Freque } \\
\text { ncy } \\
\text { Total }\end{array}$ & $\begin{array}{l}\text { Percent } \\
\text { age }\end{array}$ & $\begin{array}{c}\text { Freque } \\
\text { ncy } \\
\text { Total }\end{array}$ & $\begin{array}{l}\text { Percent } \\
\text { age }\end{array}$ & & \\
\hline & \multirow{2}{*}{\multicolumn{2}{|c|}{$\begin{array}{l}\text { Grade } 3 \\
\text { Grade } 4\end{array}$}} & 0 & 0 & 0 & 0 & 0 & 0 & 0 & 0 & 0 & 0 \\
\hline & & & 0 & 0 & 0 & 0 & 0 & 0 & 0 & 0 & 0 & 0 \\
\hline \multirow{6}{*}{ 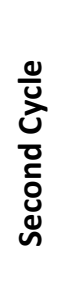 } & \multicolumn{2}{|c|}{ Grade 5} & 0 & 0 & 2 & 2.5 & 0 & 0 & 0 & 0 & 2 & 0.3 \\
\hline & \multirow{3}{*}{\multicolumn{2}{|c|}{$\begin{array}{l}\text { Grade } 6 \\
\text { Grade } 7 \\
\text { Grade } 8\end{array}$}} & 0 & 0 & 5 & 6.2 & 0 & 0 & 0 & 0 & 5 & 0.7 \\
\hline & & & 1 & 0.3 & 0 & 0 & 0 & 0 & 0 & 0 & 1 & 0.1 \\
\hline & & & 9 & 2.4 & 2 & 2.5 & 19 & 12.8 & 0 & 0 & 30 & 4.4 \\
\hline & \multicolumn{2}{|c|}{ Grade 9} & 63 & 16.7 & 10 & 12.3 & 4 & 2.7 & 1 & 1.3 & 78 & $\begin{array}{c}11 . \\
4\end{array}$ \\
\hline & \multicolumn{2}{|c|}{ Grade 10} & 31 & 8.2 & 2 & 2.5 & 7 & 4.7 & 17 & 21.5 & 57 & 8.5 \\
\hline \multirow{6}{*}{ 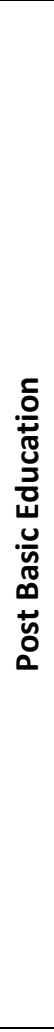 } & \multirow[b]{3}{*}{$\begin{array}{l}\text { ㄱ. } \\
0 \\
\frac{1}{0} \\
\frac{\pi}{0} \\
0\end{array}$} & $\begin{array}{c}\text { This is } \\
\text { my } \\
\text { homelan } \\
\text { d }\end{array}$ & 85 & 22.6 & 8 & 9.9 & 18 & 12.2 & 2 & 2.5 & $\begin{array}{c}11 \\
3\end{array}$ & $\begin{array}{c}16 . \\
5\end{array}$ \\
\hline & & $\begin{array}{c}\text { Economi } \\
\text { c } \\
\text { Geograp } \\
\text { hy }\end{array}$ & 35 & 9.3 & 6 & 7.4 & 3 & 2 & 37 & 46.8 & 81 & $\begin{array}{c}11 . \\
8\end{array}$ \\
\hline & & $\begin{array}{c}\text { Islamic } \\
\text { civilizatio } \\
\mathrm{n} \\
\end{array}$ & 10 & 2.7 & 1 & 1.2 & 1 & 0.7 & 0 & 0 & 12 & \\
\hline & & $\begin{array}{c}\text { This is } \\
\text { my } \\
\text { homelan } \\
\text { d }\end{array}$ & 74 & 19.7 & 38 & 46.9 & 7 & 4.7 & 0 & 0 & $\begin{array}{c}11 \\
9\end{array}$ & $\begin{array}{c}17 . \\
4\end{array}$ \\
\hline & & $\begin{array}{l}\text { Geograp } \\
\text { hy and } \\
\text { modern } \\
\text { technolo } \\
\text { gies }\end{array}$ & 7 & 1.9 & 0 & 0 & 5 & 3.4 & 7 & 8.9 & 19 & 2.8 \\
\hline & \begin{tabular}{l} 
ㄱ \\
\multirow{1}{0}{} \\
$\frac{0}{0}$ \\
0
\end{tabular} & $\begin{array}{c}\text { The } \\
\text { world } \\
\text { around } \\
\text { me }\end{array}$ & 61 & 16.2 & 7 & 8.6 & 84 & 56.8 & 15 & 19 & $\begin{array}{c}16 \\
7\end{array}$ & $\begin{array}{c}24 . \\
4\end{array}$ \\
\hline \multicolumn{3}{|c|}{ First Cycle Total } & \multicolumn{2}{|c|}{0} & \multicolumn{2}{|c|}{0} & \multicolumn{2}{|c|}{0} & \multicolumn{2}{|c|}{0} & 0 & 0 \\
\hline \multicolumn{3}{|c|}{ Second Cycle Total } & \multicolumn{2}{|c|}{104} & \multicolumn{2}{|c|}{21} & \multicolumn{2}{|c|}{30} & \multicolumn{2}{|c|}{18} & $\begin{array}{c}17 \\
3 \\
\end{array}$ & $\begin{array}{c}25 . \\
3\end{array}$ \\
\hline \multicolumn{3}{|c|}{$\begin{array}{c}\text { Post Basic } \\
\text { Education Total }\end{array}$} & \multicolumn{2}{|c|}{272} & \multicolumn{2}{|c|}{60} & \multicolumn{2}{|c|}{118} & \multicolumn{2}{|c|}{61} & $\begin{array}{c}51 \\
1\end{array}$ & $\begin{array}{c}74 . \\
7\end{array}$ \\
\hline \multicolumn{3}{|c|}{ Total } & & & & & & & & & $\begin{array}{c}68 \\
4\end{array}$ & \\
\hline & Perce & entage & & & 11. & & & & & & & \\
\hline
\end{tabular}

The results of Table 6 indicate that the post-basic education for the 11th and 12th grades comes first in the degree of inclusion of the concepts of knowledge economy according to the four indicators with a total of 
511 frequencies $(74.7 \%)$, followed by the second cycle Basic Education with a total of (173) frequencies (25.3\%). The results showed that the first cycle did not include any concepts of knowledge economy.

This may be due to the nature of social studies curricula that deal with human interaction with the surrounding environment in the social, economic and natural fields; Al-Adwan (2009) indicates that social studies curricula are centered on studying the relationship between man and society in which he lives and the relationship of that society with other societies. It is also interested in studying the fields of activity and interactions of man and its relationship to the environment and the problems that resulted from those interactions. The curriculum of the first cycle is considered one of the oldest in the curriculum of social studies books even if the year of printing indicates the newness of its printing. The meaning of reprinting in the Ministry's curricula does not mean modifying or developing the content and updating it. In addition, the nature of the age group of the first cycle of basic education focuses on building the role model by teaching students the most prominent historical and national figures such as Ahmed bin Majid and Al-Khalil bin Ahmed in the social studies textbook for the fourth grade (Ministry of Education, 2017).

Interest in incorporating the concepts of knowledge economy in the second cycle is more evident than the first cycle, but the inclusion of these concepts is still weak in this cycle with a difference in the inclusion of these concepts from one grade to another. This may be due to the deeper and more extensive nature of knowledge at this age stage of learning. The variation in the inclusion of these concepts and the high percentage of the inclusion of the concepts of the third indicator are due to the nature of the activities assigned to students in some lessons that require research and the preparation of reports and articles about them.

The results also indicate that the textbook "the world around me" occupies the first place in the degree of inclusion of the concepts of knowledge economy with 167 frequencies $(24.4 \%)$, followed by the textbook "this is my homeland" for the twelfth grade with a 119 frequencies $(17.4 \%)$, and then the textbook "this is my homeland" for the eleventh grade with a total of (113) frequencies (16.5\%). The high rate of inclusion of these post-basic textbooks is due to the fact that it is a pre-university stage in which students need to prepare and develop their knowledge of the global developments and economic developments required by the labor market that lead to the progress and development of countries, which contributes to the formation of a broad knowledge base and form a picture of the future career. They have facilitated their integration into university education or the labor market. In addition, the age group of the 11th and 12th graders requires more profound and updated information and knowledge compared to the previous educational stages. The books of this stage are the most updated and updated compared to the rest of the curriculum books. These results are consistent with the results of some studies in the Arab world such as the study of aggression. Al Edwan and Hamaidi (2010) pointed out that the content of the textbooks of the social studies curriculum in Jordan does not refer to the philosophy of the knowledge-based economy directly, and Taman (2015) indicated that the concepts of knowledge economy related to e-commerce in Egypt were included. In economics for high school business

\section{Conclusion}

The results of this study in general indicate that the ministerial decision taken on the development of social studies curricula is a great opportunity to reflect in depth on the contents of this article, which should reflect the major shifts related to its various fields, especially the concepts of knowledge economy. Two paths can be used in building development: the first is the standards of the National Council for Social Studies in the United States of America. It is an institution whose standards affect the development of social studies in many countries of the world, especially since there are standards related to economy, technology, such as the standard of science, technology, and society, which is one of National Council for Social Studies Standards in the United States of America. It explained that social studies programs should include experiments that provide a study of the relationships between science, technology and society, and how science and technology influence beliefs, knowledge and everyday life (NCSS, 2010).

The second is to benefit from what has been achieved at the national level in the formulation of the concepts of knowledge economy and the mechanisms of its educational inclusion. This includes the Oman Digital Strategy 2040, which supports the transformation towards knowledge economy (ITA, 2018), the National 
Innovation Strategy, which focuses on the Sultanate's entry into the knowledge economy through the achievement of a national economy based on innovation through the creation of a national innovation system (Research Council), Oman Vision 2040, which considers teaching, learning, scientific research and national capabilities as one of the most important national priorities through a strategic orientation based on inclusive and sustainable education and scientific research leading to a knowledge society and competing national capabilities by focusing on raising the quality of education, higher education and curriculum development so that graduates of the education system are qualified to enter the local and global labor markets with competing abilities, skills and competencies that meet the productivity and competitiveness levels required to build a knowledge economy (Supreme Council for Planning, 2018).

Based on the results of the study, the researchers introduce the following recommendations for policy makers:

- The need to include the concepts of knowledge economy to be an integral part in the curricula in the various academic stages of schooling and not limited to certain stages with the need to be renewed and updated constantly.

- Curriculum makers should be constantly informed and renewed and have a high level of awareness of these national trends and strategies that help them in building and developing curricula in the light of them, so that their contents and concepts are reflected in the content of the curriculum, its objectives, activities, methods of evaluation, teaching methods and other sources of learning to understand and absorb the knowledge economy concepts.

\section{REFERENCES}

Abu Jahleh, R.(2014). The impact of an educational program in science based on knowledge economy in the acquisition of scientific concepts and science processes (Unpublished doctoral Disseration). Amman Arab University. Jordan.

Al- Nimrawi, Z.(2014). Evaluating the quality of the mathematics textbook for the second secondary scientific grade in Jordan in the light of the knowledge economy from the point of view of its teachers. Damascus University Journal, 30 (2), 241-272.

Al- Sharif, T.(2016). A strategic vision to develop the function of community service in Saudi universities (Delphi method). International Journal of Specialized Educational, 2 (5), 174-195.

Al-Barrak, A. (2011). The Degree of Effectiveness of the Jordanian Program for Development school From the teachers' perspective in Middle Badia Schools (Unpublished Master Thesis). Mutah University. Jordan.

Al-Batarseh, M. (2005). Building a training program based on the competencies of the knowledge economy for the professional development of teachers of home economics in Jordan (Unpublished doctoral thesis). Amman Arab University for Graduate Studies. Jordan.

Al-Edwan, Z\& Hamaidi, D. (2010). Evaluating social and national education textbooks based on the criteria of knowledge-based economy from the perspectives of. Social and Behavioural Sciences, 2, 2029- 2034.

Arundel, A. (2006). From the 19th to the 21st Century: Indicators for the knowledge economy. In Knowledge Economy; Challenges for Measurement (pp. 14-23).

Boulsbaa, R. (2013). Sustainable Human Development and Knowledge Economy in Arab Countries: Reality and Challenges Comparative Study: United Arab Emirates - Algeria - Yemen (Unpublished Master Thesis). Farhat Abbas Setif University. Algeria.

Bustanji, M. (2011). Evaluation of the training program for the general curriculum framework and assessment based on the knowledge economy in Karak Governorate - Jordan according to Tyler Goal Model. Journal of the Faculty of Education in Ismailia, 21, 87-156.

Ceri , V. (2001). Building the knowledge economy. Journal of Computing and Information Technology. 9 (3), 177183. 
Chen, D. H., \& Dahlman, C. J. (2005). The knowledge economy, the KAM methodology and World Bank operations. World Bank Institute Working Paper, (37256).

Cooperation, A. P. E. (2000). Towards knowledge-based economies in APEC. Report by APEC Economic Committee, November.

Dimmock, C \& Goh, J. W. (2011). Transformative pedagogy, leadership and school organisation for the twenty-first-century knowledge-based economy: The case of Singapore. School Leadership $\mathcal{E}$ Management, 31(3), 215-234.

European Commission. (2008) Indicators for the Knowledge-Based Economy : Summary Report 2008. Retrieved From: https://www.unitrier.de/fileadmin/fb4/projekte/SurveyStatisticsNet/KEI-WP2-D2.5.pdf.

Gomaa, M. (2009). Education development and its role in the knowledge economy. Research submitted to the First International Conference on e-learning and distance learning: the learning industry for the future, Riyadh: Taif University.

Hadad, S. (2017). Knowledge Economy: Characteristics and Dimensions. Management Dynamics in the Knowledge Economy, 5 (2), 2392-8042.

Hansen, B. (2011). Adapting in the knowledge economy lateral strategies for scientists and those who study them (Unpublished PhD thesis). The IT University of Copenhagen Business School.

Hogan,T. (2011). An overview of the knowledge economy with a focus on arizona. a report from the productivity and prosperity project (P3). Center for Competitiveness and Prosperity Research. Arizona State University.

Houghton, J. \&Sheehan, P. (2000). A primer on the knowledge economy. Paper prepared for the National Innovation Summit, organised by the Department of Industry, Science and Resources. Melbourne: Centre for Strategic Economic Studies Victoria University of Technology.

Information Technology Authority. (2018). National strategy for digital Oman society and e- government - digital Oman. Information Technology Authority :Sultanate of Oman.

Ministry of Education\& World Bank. (2012). Education in Oman. The Ministry of Education. Sultanate of Oman.

Ministry of Education. (2018). Ministerial Decree No. (313/2018) establishing two committees: main and technical to formulate general policies for social studies curricula for grades (3-12). Sultanate of Oman.

Mohammed bin Rashid Al Maktoum Foundation\& United Nations Development Program. (2015). Arab knowledge index 2015. Dubai: Al Ghurair House for Printing, Publishing and Distribution.

Muhammad, A. (2014). Knowledge economy and its development trends. Amman: Dar Al-Masirah for Publishing \& Distribution.

National Curriculum Standards for Social Studies (2010 edition). National Council for the Social Studies. Retrieved from: https://www.socialstudies.org /standards /strands.

OECD. (1996). OECD Science technology and industry scoreboard: Benchmarking knowledge-based economies, Paris.

Powell, W. W., \& Snellman, K. (2004). The knowledge economy. Annu. Rev. Sociol., 30, 199-220.

Robertson, S. L. (2008). Producing knowledge economies: The World Bank, the KAM, education and development. Re-reading Education Policies: Studying the Policy Agenda of the 21th Century. Netherlands: Sense Publishers.

Salem, M. I. (2014). The role of universities in building a knowledge-based economy in Saudi Arabia. International Business \& Economics Research Journal (IBER), 13(5), 1047-1056.

Scientific Research Council. (2018). National innovation strategy. Sultanate of Oman. Sultanate of Oman: Scientific Research Council.

Shiryaev, D., Artemova,E., Zelinskaya, M., Novoselov, S., Galiullina, S\& Pismennaya, E. (2016). “Knowledge Economy" as a resource for the intensification of socio-economic transformation of the regional economic space. International Review of Management and Marketing, 6, 232-237. 
Sundac, D\& Krmpotic, I. (2011). Knowledge economy factors and the development of knowledge-based economy. Croatian Economic Survey, 13 (1). 105-14.

Supreme Council for Planning. (2019). Vision 2040 Initial Vision Document, Sultanate of Oman :Vision office.

Takroni, A. (2012). Student advisor contribution in the development of the personality of primary school student from the perspective of islamic education. (Unpublished Master Thesis). Umm Al Qura University. Saudi.

Taman, A. (2016). A proposed model based on integrated learning to develop the curriculum of economics in commercial secondary schools to develop the concepts of knowledge economy in the information age. Journal of the Faculty of Education, 57, 1-45.

Tarkhan, M. (2014). Arab educational leadership and the challenges of education in the era of globalization Jordan is a future scientific research model in the style of Delphi. Ramallah: Dar Al Shorouk for Publishing and Distribution.

Tocan, M. (2012). Knowledge based economy assessment. Journal of Knowledge Management, Economics and Information Technology, 5, 199-213.

World Bank (IBRD). (2003). Lifelong learning in the global knowledge economy: challenges for developing countries: a World Bank report. World Bank, Washington, District of Columbia.

World Bank. (2007). Building knowledge economies: Advanced strategies for development. World Bank.

Zoubi, I. (2010). The effect of a developer curriculum in Islamic education in the principles of knowledge economy in achievement and the development of creative thinking among basic stage students in Jordan (Unpublished PhD Thesis). Amman Arab University. Jordan. 